\title{
Determinants of Individual Investor Behaviour in Stock Investment Decisions
}

\author{
Reza Widhar Pahlevi and Indri Irma Oktaviani \\ Management Departemen, Economy Faculty, Universitas Islam Indonesia, Indonesia \\ Jl. Prawiro Kuat, Ngringin, Condongcatur, Yogyakarta, 55283, Indonesia
}

\section{Info Article}

History article:

Approved: 8 December 2018

Published: 25 December 2018

\begin{tabular}{l}
\hline Keywords: \\
Investor Attitude; Investor \\
Behavior; Financial Behavior; \\
and Stock Investment Deci- \\
sion
\end{tabular}

ISSN (print) : 2598-7763

ISSN (online): 2598-7771

\section{Abtract}

The quality of individual investor behavior in making stock investment decisions is very important to be understood as a reference of the movement of the capital market. This research using descriptive analysis technique, and inferential analysis, using Structural Equation Model (SEM), using the help of software PLS (Partial Least Square). The population used in this study are individual investors (student in Yogyakarta area) who actively transact on the Indonesia Stock Exchange. The sample used in this research is the investor who is still a member of the Capital Market Study Group (KSPM) at several universities in Yogyakarta. Based on the result of the research, It can be concluded that the attitude, subjective norm, perception of behavior control, subjective norm, overconfidence, excessive optimism, herd behavior have positive effect on investors' intention in investing, and there is no influence between psychology of risk to investor attitude in investing.

Citation: Pahlevi, Reza Widhar and Oktaviani, Indri Irma. (2018). Determinants of Individual Investor Behaviour in Stock Investment Decisions. Accounting and Financial Review, 1 (2)

\begin{abstract}
Abstraks
Kualitas perilaku investor individu dalam membuat keputusan investasi saham sangat penting untuk dipahami sebagai referensi pergerakan pasar modal. Penelitian ini menggunakan teknik analisis deskriptif, dan analisis inferensial, menggunakan Structural Equation Model (SEM), menggunakan bantuan perangkat lunak PLS (Partial Least Square). Populasi yang digunakan dalam penelitian ini adalah investor individu (pelajar di daerah Yogyakarta) yang aktif bertransaksi di Bursa Efek Indonesia. Sampel yang digunakan dalam penelitian ini adalah investor yang masih menjadi anggota Kelompok Studi Pasar Modal (KSPM) di beberapa universitas di Yogyakarta. Berdasarkan hasil penelitian, dapat disimpulkan bahwa sikap, norma subyektif, persepsi pengendalian perilaku, norma subyektif, kepercayaan berlebihan, optimisme berlebihan, perilaku kawanan berpengaruh positif terhadap niat investor dalam berinvestasi, dan tidak ada pengaruh antara psikologi risiko terhadap sikap investor dalam berinvestasi.
\end{abstract}

JEL Classification: G31, G32, G34

DOI: https://doi.org/10.26905/afr.v1i2.2427 $\square$ Corresponding Author:
Reza Widhar Pahlevi
Tel. /Fax : 0817276108
E-mail: rezawp@uii.ac.id

\section{INTRODUCTION}

Investors need information which are important factors as a basis for determining investment choices (Halim, 2005). From the available information, then form a decision-making model in the form of investment assessment criteria to enable investors to choose the best investment among ava- ilable investment alternatives. Investor behavior in stock investment decision making is projected with the intention of individual investors in choosing stocks. The intentions of individual inves-tors are reflected in the estimation of stock returns that are calculated using various information. Intention itself is an intention to behave that grows because of information that provokes a person's motivation to take a decision (Prawirasasra, 2016). 
There are various factors that can influence an investor's decision to act in choosing the right stock. Among them, such as news, information, politics, risk, security, policy, rumors, external factors (global markets), and consideration of market participants beliefs in making intentions to invest in shares (Lubis, et al, 2013). The main issue in this study is about the behavior of individual investors in making stock investment decisions. Attention to investment issues reflects attention to information in interpreting information for decision making. For investors, information is a signal that functions as a stimulus that influences cognitive processes because it informs the company's financial performance, company prospects, uncertainty, expected values, and means of management responsibility to stakeholders.

Meanwhile, in carrying out investment activities, the basic knowledge of investment is very important to avoid irrational investment practices (gambling), bully investments and cultural follow-up. Therefore, to increase public investment knowledge and advance the Indonesian capital market, the Indonesia Stock Exchange collaborates with PT. Kustodian Sentral Efek Indonesia (KSEI), PT. Kliring Penjaminan Efek Indonesia(KPEI) and securities companies then organized various educational programs such as seminars, workshops, interactive talk shows, School/Capital Market Training and establishing stock exchanges at several universities.

Some research results show that attitudes have a significant effect on investor intentions. The results show rationally that individual investors are more profitable in investing, it makes sense to assume that if individual investors prefer these investments, they are more motivated to take actions that benefit than less profitable investments (Phan and Zhou, 2014, Shih and Fang 2004, Ramayah and Suki 2006, Michael 2011).

The main issue in this research is about the behavior of individual investors in stock investment decision making, and the purpose of this study is to examine and obtain empirical evidence of the behavior of individual investors in stock investment decisions. Research on investor behavior in making stock investment decisions is very important, because capital market movements reflect the economic conditions of a country. During this time the movement of the capital market in Indonesia is still very volatile, where the gap between the increase and decrease in the IHSG is still very high. This reflects the instability of economic conditions in Indonesia which inciden- tally still includes developing countries. The problem of developing countries is the gap in the quality of human resources that is still high, and in this study the human resources in question are individual investors, so that the quality of the behavior of individual investors in stock investment decisions is very important to understand as a reference for capital market movements.

\section{HYPOTHESIS DEVELOPMENT}

\section{Attitudes and Investor Intention in Investing}

Prospect theory was developed by two psychologists, Daniel Kahneman and Amos Tversky in the early 80s which basically covered two disciplines, psychology and economics (psychoeconomics) (Lubis, et al, 2013). Prospect theory starts with Kahneman and Tversky's research on human behavior which is considered strange and contradictory in making a decision. Prospect theory is a theory related to attitudes that focus on decision making processes that affect an investor's valuation system (Luong and Ha, 2011). In short, it can be said that prospect theory shows that people will have an irrational tendency to be more reluctant to risk profits than losses. In a loss condition, someone will tend to be more inclined to bear the risk than in a successful condition. A person will feel as if the value of losing a certain amount of money in a bet is more painful than the winning value of the same amount of money, so that in a loss situation people are more determined to risk (Phan and Zhou, 2014). The results show that individual investors are more profitable in investing, it makes sense to assume that if individual investors prefer these investments, they are more motivated to take actions that benefit than less profitable investments (Phan and Zhou, 2014, Shih and Fang 2004, Ramayah and Suki 2006, Michael 2011).

$\mathrm{H}_{1}$ : Attitudes have a positive effect on investor intentions in investing

\section{Subjective Norms and Investor Intention in In- vesting}

Ajzen (2005) assumes that subjective norms are determined by the existence of normative beliefs and the desire to follow (motivation to comply). Normative beliefs (normative belief) are beliefs about normative expectations of others that motivate someone to fulfill these expectations (normative belief and motivation to comply). Normative beliefs are indicators that then produce subjective norms (subjective norm). So subjective norms are a person's perception of social influence 
in shaping certain behaviors. Subjective norms are not only determined by referents, but also determined by motivation to comply. In general, individuals who believe that most referents will approve of themselves display certain behaviors and motivations to follow certain behaviors will feel social pressure to do so. Conversely, individuals who believe that most referents will not approve of themselves display certain behaviors, and there is no motivation to follow certain behaviors, this will cause them to have a subjective norm that puts pressure on them to avoid doing these behaviors (Ajzen, 2005).

$\mathrm{H}_{2}$ : Subjective norms have a positive effect on investor intentions in investing

\section{Behavioral Control Perception and Investor Inten- tion in Investing}

Perception of behavioral control is very important when an individual's confidence is in a low condition. Sophisticated investors will use their social references (subjective norms) as controls to strengthen their confidence in the factors that can support the analysis they have done when they need additional confidence in choosing a stock (Masrurun and Heri, 2015). Behavioral control perceptions are based on individual beliefs about supporting factors and or intention-inhibiting factors to conduct a behavior. Strong confidence in yourself, capital support, and technology support will support investors' high intention to choose a stock. Conversely when investor confidence in oneself, capital support, and technology support is weak, the investor's intention to choose shares is low. This result is also in line with the research of Philmore and Broome (2010), Masrurun and Heri (2015) and Phan and Zhou (2014) who found that the perception of behavioral control is a significant predictor of predicting investor intentions in investing.

$\mathrm{H}_{3}$ : Perception of Behavioral Control has a positive effect on investor intentions in investing

\section{Subjective Norms and Investor Attitudes in In- vesting}

Bhattacherjee (2000) states that subjective norms are influenced by two forms, interpersonal influences and external influences. Interpersonal influences come from friends, family members, colleagues, superiors, and experienced individuals. Hite (1988) shows that peers (peers) have a strong influence on the value of preferences and individual behavior. In general, the more individuals perceive that their social referrals recommend doing a behavior, then the individual will tend to feel social pressure to do this behavior, on the contrary, the more the individual perceives that his social referral recommends not doing a behavior, then the individual will tend to feel social behavior not to behave. (Phan and Zhou, 2014).

$\mathrm{H}_{4}$ : Subjective Norms have a positive effect on the attitude of investors in investing

\section{Overconfidence and Investor Attitudes in Invest- ing}

Overconfidence is a feeling of excessive selfconfidence. Overconfidence makes investors overestimate the knowledge possessed by investors themselves, and underestimates the predictions made because investors overestimate their capabilities (Nofsinger, 2005). The results of Odean's (1999) study found that investors in stock transactions tend to do with a high trading volume, this indicates that investors in stock transactions tend to overconfidence. Farooq et al (2015) revealed that when people are faced with uncertainty, they tend to take overconfidence decisions. Kahneman and Tversky's (1973) research and Kengatharan and Kengatharan (2014) state that differences in overconfidence levels will lead to differences in interpreting and evaluating information so that it will produce differences in finding solutions.

Overconference also influences investors to take risk behavior, rational investors try to maximize profits while minimizing the amount of risk taken (Nofsinger, 2005). Overconvidence can also cause investors to assume greater risk in making decisions to invest (Anum and Ameer, 2017). The indicator used is investor knowledge, can help investors to invest; the ability of investors, can help investors to invest (Sarkar and Sahu, 2017).

$\mathrm{H}_{5}$ : Overconfidence has a positive effect on the attitude of investors in investing

\section{Excessive Optimism and Investor Attitudes in Investing}

Investors who are too confident (Excessive Optimism) usually overestimate the role of their own information and therefore too trust their abilities (Talha, et al, 2015). Excessive optimism usually comes from overconfidence and captures the perception that future events will be better and more positive than the current situation (Mitroi, 2014). Overly optimistic investors may believe that bad investments will not harm their portfolios and therefore they expect too much from the market and from investment opportunities (Wang 2001). However, excessive optimism has a negative effect when it comes to investments that are very risky. 
What's more, if it is related to too much selfconfidence and excessive optimism (Wang 2001).

$\mathrm{H}_{6}$ : Excessive Optimism has a positive effect on the attitude of investors in investing

\section{Herd Behavior and Investor Attitudes in Invest- ing}

Herding in financial markets is identified as a tendency for investor behavior to follow the actions of other investors (Luong and Ha, 2011; Setiawan et. al. 2018). In the behavioral perspective, herding can lead to the appearance of emotional distortions. Investors prefer to do herding when they believe that herding can help them to obtain useful and trustworthy information (Lakshmi, et al, 2013). Herding behavior (social proof), is driven by the desire to be part of the crowd or the assumption that the crowd is the most knowledgeable (Waweru et al 2008). The securities company needs to continue to update everything related to the facilities and infrastructure used by investors. Good facilities and infrastructure, for example, internet network systems, computer devices, convenience of space for investor activities and so on are supporting the smooth process of making investment decisions. Investors who are not affected by the actions of other investors when making investment decisions occur when the investor is convinced of the analysis he has done, so he will not make irrational decisions. A good analysis can be done if it is supported by good facilities and infrastructure when conducting the analysis. Thus, in the end profits will be enjoyed by all parties, both for investors and securities companies (Dar and Hakeem, 2015).

$\mathrm{H}_{7}$ : Herd Behavior has a positive effect on the attitude of investors in investing

\section{Psychology of Risk and Investor Attitudes in In- vesting}

Risks can be interpreted as deviations from what is expected (Lubis, et al, 2013). Words of deviation can mean deviating better than expected or not better. This understanding is in accordance with modern investment theory which symbolizes risk with a standard deviation that can be positive and can also be negative. This means that the risks contained in the opportunity to get a return (return) greater than expected, but can also be smaller than expected (Lubis, et al, 2013).

In modern investment decision making, knowing one's risk tolerance is very important in developing financial plans and investments in addition to knowing the goals, time horizon, and financial stability of an individual (Anbar and Melek,
2010). Investment managers who ignore this risk tolerance may find it difficult to implement plans and achieve their goals. Financial risk tolerance is a key element that needs to be considered in making investment decisions for both investment managers and investors. Risk tolerance is the level of uncertainty that a person can accept in facing certain risks and refers to the attitude of investors in investing (Phan and Zhou, 2014).

$\mathrm{H}_{8}$ : Psychology of Risk has a positive effect on the attitude of investors in investing

\section{DATA DAN METHODS}

This research uses primary data, to get the primary data by the researcher, the survey method will be used by giving a set of questionnaires related to variables. Respondents were asked to give responses to the contents of the questionnaire in accordance with the circumstances felt or experienced by the respondent. The researcher will use a Likert Scale approach with six gradations of cue, from the lowest score (ie 1) to the highest score (ie 6). The population used in this study are individual investors who actively transact on the Indonesia Stock Exchange. The sample used in this study were investors who were still students as members of the Kelompok Studi Pasar Modal (KSPM) at several universities in Yogyakarta. Universities that have KSPM organizations in Yogyakarta. In this study, data analysis using Structural Equation Model (SEM), using the help of PLS (Partial Least Square) software.

\section{RESULT}

\section{Convergent Validity on the Outer Model}

Convergent Validity refers to the validity of items making up a latent with reflective indicators. Convergent validity is made of composite reliability $(C R)>0.6$. This means that there is no measurement error on the outer model and all of the latent variables can be used to predict structural functions on the inner model. Based on the test results the PLS algorithm shows all indicators of each variable declared valid. The variables used in the study include: attitude towards the behavior, behavioral intention, excessive optimism, herd behavior, overconfidence, perceived behavioral control, psychology of risk and subjective norm.

\section{Discriminant Validity on the Outer Model}

Discriminant validity is done to ensure that each concept of each latent variable is different from other variables. The model has good discrimi- 
nant validity if each loading value of each indicator of a latent variable has the largest loading value with other loading values against other latent variables.

Based on the result of data analysis processing to assess the outer convergent validity model and discriminant validity by using PLS, the value of the outer model or the correlation between the indicators with the variables in the study has met the convergent validity because all of them have a loading factor above 0.60 . The table 1 shows that the variables used in this study is reliable. It is known that the model in this study has a good discriminant validity value as shown in table 2 .

Table 1. Output Construct Reliability and Validity Test

\begin{tabular}{lccc}
\hline Variabel & Alpha Cronbach & Composite Reliability & Average Variance Extracted (AVE) \\
\hline Attitude Toward the Behavior & 0.959 & 0.910696 & 0.629942 \\
Behavioral Intention & 0.930 & 0.889227 & 0.617897 \\
Excessive Optimism & 0.944 & 0.881158 & 0.598367 \\
Herd Behavior & 0.951 & 0.860834 & 0.553939 \\
Overconfidence & 0.957 & 0.873339 & 0.580549 \\
Perceived Behavioral Control & 0.857 & 0.836419 & 0.506794 \\
Psychology of Risk & 0.934 & 0.851650 & 0.534919 \\
Subjective Norm & 0.954 & 0.916955 & 0.734210 \\
\hline
\end{tabular}

Tabel 2. AVE Root Outputs

\begin{tabular}{lllllllll}
\hline & ATB & BI & EO & HB & OVF & PBC & PR & SN \\
\hline ATB & 1.000000 & & & & & & & \\
BI & 0.739038 & 1.000000 & & & & & & \\
EO & 0.574859 & 0.547238 & 1.000000 & & & & \\
HB & 0.436670 & 0.362560 & 0.379613 & 1.000000 & & & \\
OVF & 0.596021 & 0.565573 & 0.723316 & 0.393590 & 1.000000 & & & \\
PBC & 0.413612 & 0.496827 & 0.423976 & 0.378642 & 0.425740 & 1.000000 & & \\
PR & 0.324454 & 0.414552 & 0.300327 & 0.479503 & 0.319789 & 0.320015 & 1.000000 & 1.000000 \\
SN & 0.485318 & 0.579526 & 0.563286 & 0.284171 & 0.570937 & 0.553404 & 0.360473 & \\
\hline
\end{tabular}

Notes: ATB (attitude towards the behavior), BI (behavioral intention), EO (excessive optimism), HB (herd behavior), OVF (overconfidence), PBC (perceived behavioral control), PR (psychology of risk) and SN (subjective norm).

\section{Structural Model Testing (Inner Model)}

Inner model testing or structural model is done to see the relationship between constructs, significance values and R-square of the research model. The structural model was evaluated using the R-square for the dependent construct $t$ test and the significance of the structural path parameter coefficient. The table 3 shows that attitude toward the behavior can be adjusted by investor intentions as much as $45 \%$ and behavioral intentioncan be adjusted by investor intentions as much as $62 \%$.

Table 3. R-square

\begin{tabular}{lr}
\hline & $R$-square adjusted \\
\hline Attitude Toward the Behavior & 0,449544 \\
Behavioral Intention & 0,621943 \\
\hline
\end{tabular}

\section{Q-square}

Q-square was used to evaluate the model of how well the observation value is generated by the model and its parameter estimation. The value of
$\mathrm{Q}^{2}$ is greater than zero indicating that the model has a predictive relevance value, conversely, a square value of less than zero indicating that the model lacks predictive relevance value (Ghozali, 2008). The calculation of Q2 values from this research shown model 1. From the calculation model 1 it can be seen that the model has a good predictive relevance value

$$
\begin{aligned}
\mathrm{Q}^{2}= & 1-(1-\text { RAttitude Toward the Behavior })(1- \\
& \text { RBehavioral Intention }) \ldots \ldots \ldots \ldots . \ldots(\text { model } 1) \\
\mathrm{Q}^{2}= & 1-(1-0,449544)(1-0,621943) \\
\mathrm{Q}^{2}= & 0,7919
\end{aligned}
$$

\section{t-statistics}

This test was conducted to test the relationships between construct. Before performing an inner evaluation of the t-statistics test model, a bootstrapping of SmartPLS software was performed by resampling 210 iterations. The results of the bootstrapping model are presented in Figure 1.

Additionally, to assess the type of relation- 
ship, it can be seen in the original sample value. The relationship is positive if the original sample value indicates a positive number. The relationship is negative if the original sample value shows a negative number. The results of path analysis are shown in table 4 . The results of the internal model tests as written in Table 4 show that out of the seven lines all were statistically significant, except for risk psychology.

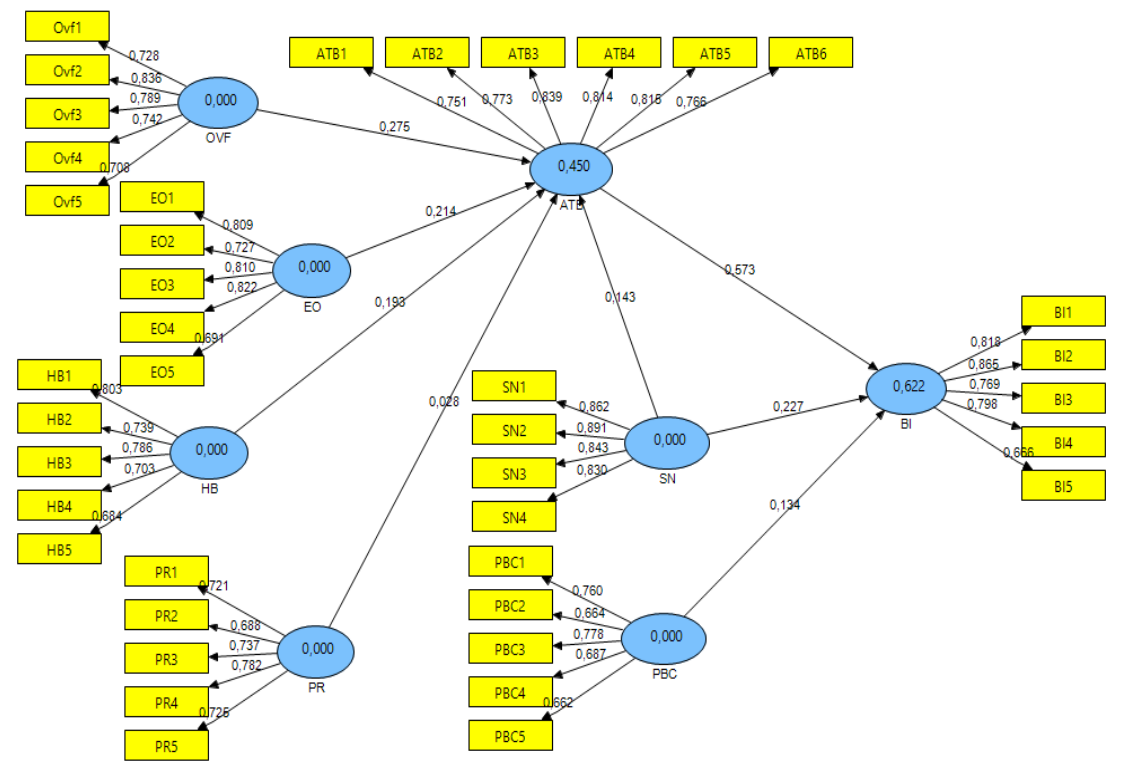

Figure 1. Bootstrapping Model

Table 4. Path Coefficients Result

\begin{tabular}{lcccl}
\hline & Original Sample & t Statistics & t table & \multicolumn{1}{c}{ Result } \\
\hline $\mathrm{ATB} \rightarrow$ BI & 0.573408 & 7.910713 & 1.6551 & Positive and significant \\
EO $\rightarrow$ ATB & 0.213846 & 1.945222 & 1.6551 & Positive and significant \\
$\mathrm{HB} \rightarrow$ ATB & 0.193245 & 1.789223 & 1.6551 & Positive and significant \\
$\mathrm{OVF} \rightarrow$ ATB & 0.274629 & 2.606524 & 1.6551 & Positive and significant \\
$\mathrm{PBC} \rightarrow$ BI & 0.133984 & 1.933368 & 1.6551 & Positive and significant \\
$\mathrm{PR} \rightarrow$ ATB & 0.028203 & 0.251667 & 1.6551 & Has no effect \\
$\mathrm{SN} \rightarrow$ ATB & 0.142984 & 1.662014 & 1.6551 & Positive and significant \\
$\mathrm{SN} \rightarrow$ BI & 0.227093 & 2.593923 & 1.6551 & Positive and significant \\
\hline
\end{tabular}

The results of the study show that the attitude toward the behavior has a positive influence on the investor intentions on investment. This means that Hypothesis 1 is accepted. The subjective norm has a positive influence on the investor intentions on investment. This means that Hypothesis 2 is accepted. Perceived Behavioral Control. The results of Perceived Behavioral Control has significant positive effect on the investor intensions on investment. This result means that perceived behavioral control has a positive influence on the investor intentions on investment. This means that Hypothesis 3 is accepted. Subjective Norm has significant positive effect on the investor attitude on investment. This result means that subjective norm has a positive influence on the in- vestor attitude on investment. This means that Hypothesis 4 is accepted. Overconfidence Overconfidence has significant positive effect on the investor attitude on investment. This result means that the overconfidence has a positive influence on the investor attitude on investment. This means that Hypothesis 5 is accepted. Excessive Optimism has significant positive effect on the investor attitude on investment. This result means that the excessive optimism has a positive influence on the investor attitude on investment. This means that Hypothesis 6 is accepted. Herd Behavior has significant positive effect on the investor attitude on investment. This result means that the herd behaviorhas a positive influence on the investor attitude on investment. This means that Hypothesis 7 is accepted. Psychology of Riskhas no effect on 
the investor attitude on investment. This result means that the psychology of riskhas no effect on the investor attitude on investment. This means that Hypothesis 8 is rejected.

\section{DISCUSSION}

This research has proved that attitudes, subjective norms, perception, subjective norms, overconfidence, excessive optimism, and herd behavior have a positive effect on investor intentions in investing and there is no influence between psychology of risk on the attitude of investors in investing. Phan and Zhou (2014) and Farn et al (2006) showed that there was a significant influence between subjective norms on investor intentions in stock selection. Research conducted by Philmore and Broome (2010), Masrurun and Heri (2015) serta Phan and Zhou (2014) found that perception of behavior control is a significant predictor for predicting investor intentions in investing. Overconfidence also affects investors to take the risk, rational investor try to maximize profits while minimizing the amount of risk taken (Nofsinger, 2005). Excessive optimism also has a positive impact on investment behavior and encourages investors to invest, because there are too many risk aversion behaviors that will reduce trading volume (Phan and Zhou, 2014). Risk tolerance is the level of uncertainty that a person can accept in facing certain risks and refers to the investor's attitude in investing (Phan and Zhou, 2014).Thus, this research conclude that attitude toward the behavior, subjective norm, and perceived behavioral control has a positive effect on investor intentions in investment. And also, Subjective norm, Overconfidence, Excessive Optimism, and Herd Behavior has a positive effect on investor attitude in investment. In the other hand, Psychology of Risk has no effect on the investor attitude on investment.

Research on investor behavior in stock investment decisions is very important, because capital market movements reflect the economic conditions of a country. So far, the capital market movement in Indonesia is still very volatile, where the gap between the increase and decrease in the IHSG value is still very high. in this paper the human resources refers to individual investor in making stock investment decisions are very important to be understood as a reference for capital market movements.

\section{CONCLUSION AND SUGGESTION}

This research give conclusions as follows at- titude toward the behavior, subjective norm, perceived behavioral control, subjective norm overconfidence excessive optimism and herd behavior has a positive effect on investor attitude in investment. However, psychology of risk has no effect on the investor attitude on investment.

For researchers who will examine the determinants of the behavior of individual investors in making stock investment decisions on individual investors, the number of respondents for each of the characteristic studied is proportionally balanced so that they can represent each characteristic. Further researchers can also add variables such as investment duration, income and type of investment not only stocks. In the Psychology Of Risk variable in this study proved there was no influence on investor attitude in investment, it required additional variables such as investment motives, decision types, interests in investment, investment planning and control, investor risk control. For investor, the result of this study can be used as a consideration in a profitable investment decision in accordance with the characteristic of investors.

\section{REFERENCES}

Ajzen, I. (2005). The Theory of Planned Behaviour. In: Organizational Behaviour and Human Decision Process. Amherst, MA: Elsevier. 5(10)

Anbar, A and Melek, E. (2010). An Empirical Investigation for Determining of theRelation Between Personal Financial Risk Tolerance and Demographic Characteristic, Age Academic Review. 10(2)

Anum and Ameer, B. (2017). Behavioral Factors and their Impact on Individual Investors' Decision Making and Investment Performance: Empirical Investigation from Pakistani Stock Market. Global Journal of Management and Business Research. 17(1)

Bhattacherjee, A. (2000). Acceptance of e-commerce services: the case of electronic brokerages, IEEE Transactions of Systems, Man, and Cybernetics. 30(4)

Dar, F. A. and Hakeem, I.A. (2015). The Influence of Behavioural Factors on Investors Investment Decisions: A conceptual model. International Journal of Research in Economics and Social Sciences. 5(10)

Farn, C.K. Fu, J.R., and Chao, W.P. (2006). Acceptance of electronic tax filing: A study of 
taxpayer intentions. Information $\mathcal{E}$ Management Journal. 43(1)

Farooq, Aisha, Afzal, M.A, Nadeem Sohail, and Muhammad Sajid. (2015). Factors Affecting Investment Decision Making: Evidence from Equity Fund Managers and Individual Investors in Pakistan. Journal of Basic and Applied Scientific Research. 5.(8)

Ghozali,. (2008). Model Persamaan Struktural dengan Program AMOS 16.00, Konsep dan Aplikasi, Semarang, BP UNDIP

Halim, A. (2005). Analisis Investasi Edisi kedua. Jakarta : Salemba Empat

Hite, J.M. (1998). The Evolution Of Firm Networks: From Emergence To Early Growth Of The Firm. Strategic Management Journal. 5(5)

Kahneman, D. and A. Tversky. (1973). Availability: A Heuristic for Judging Frequency and Probibality. Cognitive Psychology. 5(1)

Kengatharan, L and Kengatharan, N. (2014). The Influence of Behavioral Factors in Making Investment Decisions and Performance: Study on Investors of Colombo Stock Exchange, Sri Lanka. Asian Journal of Finance \& Accounting. 6(1)

Lakshmi, S. Visalakshmi, N. Thamaraiselvan and Senthilarasu, B. (2013). Assessing the Linkage of Behavioural Traits and Investment Decisions using SEM Approach. International Journal of Economics and Management. $7(2)$

Lubis, A. N., Isfenti, S,. Khaira, A. F., dan Juli, M. (2013). Perilaku Investor Keuangan. Medan : USU Press

Luong, L. P., and Ha, D.T.T. (2011). Behavioral Factors Influencing Individual Investors' Decision Making and Performance. Thesis. Retrieved from opeconomica.files. wordpress.com. Umea School of Business.

Masrurun, I. dan Heri, Y. (2015). Determinan perilaku investor individu dalam pengambilan keputusan investasi saham. Accounting Analysis Journal. 4(4)

Michael, L.M. (2011). An examination of the determinants of top management support of information technology projects. Doctor of Philosophy, Stevens Institute of Technology

Mitroi, A. (2014). Behavioral finance: biased individual investment decision making; like the company but dislike the investment. Theoretical and Applied Economics. 12(1)

Nofsinger, J.R. (2005). Psychologi of Investing. Second Edition. Precentice-Hall Inc. New Jersey

Odean, T. (1999). Do investors trade too much?. The Journal of American Economic Review. 89(5)

Phan, K.C. and Zhou, J. (2014). Factors Influencing Individual Investor Behavior: An Empirical Study of the Vietnamese Stock Market. American Journal of Business and Management. 3(2)

Philmore, A. and Broome, T. (2010). An Exploratory Study of Factors Influencing Investment Decisions of Potencial Investors. Department of Management Studies, University of the West Indies, Cave Hill Campus, Barbados

Prawirasasra, K.P. (2016). Behavioral finance in investment decision-making process. International Journal of Management and Applied Science. 2(7)

Ramayah, T. and Suki, N.M. (2006). Intention to use mobile PC among MBA students: implications for technology integration in the learning curriculum. UNITAR E-Journal. 2(2)

Sarkar, A.K and Sahu, T.N. (2017). Factors influencing behaviour of individual investor in stock market: a case study in West Bengal. International Journal of Commerce and Management Research

Setiawan, C.Y., Rambu, A.D., dan Robiyanto. (2018). Cognitive Dissonance Bias, Overconfidence Bias dan Herding Bias dalam Pengambilan Keputusan Investasi Saham. AFRE Accounting and Financial Review. $1(1)$

Shih, Y. and Fang, K. (2004). The use of a decomposed theory of planned behavior to study Internet banking in Taiwan. Internet Research. 14(3)

Talha, M., Ramanakumar K.P.V and Neelakantan, P.R. (2015). Investor Psychology and its Influence on Investment Decisions. MAGNT Research Report. 3(9)

Wang, F. A. (2001). Overconfidence, investor sentiment, and evolution. Journal of Financial Intermediation. 10(2) 
AFRE Accounting and Financial Review Vol. 1 (2) 2018: 53-61

Waweru, N., M., Munyoki, E., and Uliana, E. (2008). The effects of behavioral factors in investment decision-making: a survey of institutional investors operating at the Nairobi Stock Exchange. International Journal of Business and Emerging Markets. $1(1)$. 